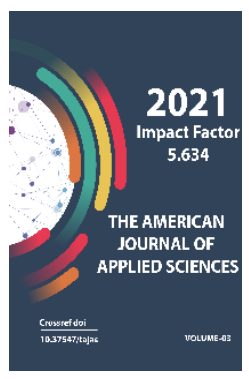

\title{
The Health-Oriented Principle Of Physical Education
}

\author{
Oybek Parpiev \\ Lecturer, Ferghana State University, Fergana, Uzbekistan
}

Copyright: Original

content from this work may be used under the terms of the creative commons attributes 4.0 licence.

\section{ABSTRACT}

Physical education and sports should be an integral part of the general culture of the citizens of the country.Therefore, the principle of health-oriented physical education requires attention to the responsibility of participants to respond to their health and when exercising. This article scientifically explores the principle that physical education is health-oriented.

\section{KEYWORDS}

Physical education, sports, health improvement, healthy lifestyle, system of education, sports pedogogy.

\section{INTRODUCTION}

Human life, health is the greatest social wealth. This transforms the issue of the formation of a healthy lifestyle in front of of family school and human upbringing, full-flegged mansions. Nation health is also naturally resolved through a healthy lifestyle. The way of life itself means mastering the leaving conditions necessary for a person to live. Depending on the method of prolongation, it can be distinguished as a healthy lifestyle and unhealthy lifestyle, and also it is necessary for the development of the formation of a healthy lifestyle, its connection 
with other sciences, the assimilation of its goals and objectives.

Consistent measures are being taken to popularize physical education and sports in our country, create the necessary conditions and infrastructure for the promotion of a healthy lifestyle among the population, especially among young people, ensure the country's worthy participation in international sport fields. The comprehensive development of physical culture and sports is a complex and difficult, multificated task, which plays a special role in the development of society. Physical education is inextricably linked with moral education. Mastering the laws of physical development, using them for the purposes of physical education is an important task of physical education. Thus, it is crucial in the social conditions and physical development of the people. Among these, labor education as well as physical education are important. Physical education is an integral part of the national culture of the peoples of the Republic of Uzbekistan, an important tool for physical and spiritual development. On January 14, 1992, Uzbekistan adopted the law on Physical culture and Sports.Since 1993, the third Sunday of April has been celebrated annually as a professional holiday for physical education and sports workers. Resolution of the Cabinet of Minister of the Republic of Uzbekistan on May 27, 1999, "On further development of physical culture and sports in the Republic of Uzbekistan" and June 3, 2003 "On continuous, sports aimed at attracting schoolchildren and students to sports on the organization of competitions" emphasizes the need to pay more attention to maintaining and strengthening the health of the population starting from preschool. It is known that the fourth priority area of the action strategy is "
Development of the social sphere", which focuses on the development of the education, culture, science, literature, art and sports, the improvement of state youth policy, special attention is paid.

\section{MAIN PART}

Also, the Resolution of the President of the Republic of Uzbekistan dated June 3, 2017 No PP-3031 "On measures for further development of physical culture and mass sports" states that "the importance of mass sports in human and family life in all regions of the country, to promote the fact that it is the basis of physical and spiritual health, to protect young people entering life with high hopes from harmful habits, to create the necessary conditions for them to realize their abilities and talents, they There are important and urgent tasks in the selection of talented athletes and the improvement of the system of targeted training. Implementation of these tasks on the basis of the education system and continuous reform will bear fruit.

Public health, physical culture and sports activities are regularly carried out during the study period in higher educational institutions, outside school hours, on holidays and weekends, in practical work, holidays in the dormitory, in the summer work of students. is carried out. Ukar can be carried out in areas such as hygiene, general training, sports and treatment.

The principle that physical education is healthoriented requires that the responsibility of those responsible for their health be taken into account when engaging in exercise. Organizers of physical culture, coaches, the state, are responsible not only for the health of those 
involved in the public, but also for strengthening it.

The health-improving and educational functions of physical education include:

- You will be in a good mood all day;

- your work will be productive, your creative activity will be strong;

- The nervous system is balanced, calm, thoughtful;

- feelings of activity, initiative, courage, friendship are formed;

- Regular exercise leads to the formation of hygienic skills;

- You lose fat, become compact, agile and agile;

- Your muscles will contract and your body will be beautiful and graceful;

- Improves blood flow in the arteries, improves the flow of oxygen and nutrients to the body and organs;

- Increases the body's defenses;

- You will be younger, more handsome, hardworking and healthy than others.

When physical exercises are used properly under the control of physician and educator, it gives a positive effect. Using wrongly may impact on human's health. Therefore, biological characteristics- age, gender, systematic accounting of health, physician and pedagogical supervision are a leading factor in educational process.

In practise, unplanned work leads to extremely negative consequences. A trivial mistake of the educator in selecting the total amounts of particle, intensity of doing, measure of exercises, selected methods can be very costly for the practitioner.
Such cases may be encountered that temporary increase in sports' results, a rise in physical fitness, causing provisionally pathological changes in the body that are not noticeable to the reputation of physical culture and sports.

Therefore, not limited to only acknowledging the evidence of medical supervision, the main focus should be on their analysis. Nonsystematic control inevitably leads to negative consequences.

The principle of linking physical education with wellness requires daily regular communication of physician, pedagogue and practitioner. The principles of physical education require an integral connection with each other. Only then they will retain their importance.

The connection of physical education with labour and military practice is its guiding principle. Only this principle represents the basic legality of physical education in our country. Its importance is to prepare members of our society for creative work and defense of the homeland.

Only in this way mental, moral, spiritual, aesthetic and labour education can be established in the process of physical education.

Our ancestor Abu Ali Ibn Sina in his 'Brief Word on Physical Exercise' emphasizes that one of the main factors of keeping health regimen is doing exercise. Puts the diet, sleep, and rest regimen after doing systematic exercise on the agenda.

He said that, doing regular, moderate, free exercises that is to engage physical exercises does not necessitate any treatment to 
eliminate the disease. Free, moderately rythmic movement allows for continuous deep breathing. This means that the body provides enough oxygen to the muscles and tissues. The body that exercises and trains does not expend too much energy on the formation of 'excess'.

To be able to find the norm of exercise in the educational process and determine its impact on health, should become an important guide and, if necessary, a character of the educational process. Principles of physical education mentioned above have a great practical effect of focusing on a number of wellness.

Therefore, observing to the general principles of the physical education system emphasizes the importance of taking into consideration to the health of the practitioners from a specialist in physical education. It follows that the effectiveness of the process of physical education will increase if the three principles are followed in time during the pedagogical process, and the requirements are perfectly fulfilled.

Nevertheless, it is beneficial for everyone to follow a healthy lifestyle, increase physical activity and start these activities today to be healthy and fit. It will inevitably give incomparable spiritual strength and support to our people, becoming a spiritual treasure not only for today, but also for future generations.

\section{CONCLUSION}

To conclude, directing students to righteousness, honesty, purity, patriotism, humanity and high morality wil have to explain the essence and content of these concepts through sports. The reason of why we are giving priority to these issues today that only a country with strong faith, convictions and moral qualities, a deep sense of national responsibility, and spiritually mature citizens can develop independently and sustainably. The great future is created and raised only when we rely on spiritually mature people.

One of the factors that introduces the country to the world and increases its prestige is a focus on the development of physical education and sports. The invaluable cultural heritage, values, customs and traditions of our people are highly recognized in the world, great achievements in sports are the results of large-scale systematic effects in this direction in our country.

\section{REFERENCES}

1. A.N.Normurodov. Physical education. Study guide. Tashkent, $2011 \mathrm{y}$.

2. A.Abdullayev, Sh.Kh.Khonkeldiyev. Theory and methods of physical education. Fergana, 2001y.

3. Sh.I.Allamurotov. Physiology and sports physiology. Textbook for Vocational Colleges. Tashkent, $2010 \mathrm{y}$.

4. Edmunds C., Biggs Kh., Izabella G. Effects of physical activity on wellbeing. Mental Health Foundation. M.:2013 y.

5. Arzikulov R.U. Fundamentals of a healthy lifestyle. Tashkent, I-II. volume, $2007 \mathrm{y}$.

6. Karimov $U$. et al. USING NEW INFORMATION TECHNOLOGIES IN DISTANCE LEARNING SYSTEM //НОВАЯ ПРОМЫШЛЕННАЯ РЕВОЛЮЦИЯ В ЗЕРКАЛЕ 
СОВРЕМЕННОЙ НАУКИ. - 2018. - С. 911.

7. A.Normurodov. National and action games. Tashkent, $2005 \mathrm{y}$.

8. I.Azimov. Sports' physiology. Tashkent, $1993 y$.

9. Karimov A., Muxammadjonov $\mathrm{X}$. INFORMATION TECHNOLOGIES: INFORMATION EDUCATION AND INFORMATICS //Экономика и социум. - 2020. - №. 8. - C. 40-43.

10. L.P.Matveyev. Theory and methodology of physical culture. M.:1994 y.

11. Yahyo, Muhammad Amin. Protection from internet threats. Supporting tutorial. Tashkent, $2016 \mathrm{y}$.

12. Tojiyev M., Salaxutdinov R. Modern information technologies in the educational process. Tashkent, $2001 \mathrm{y}$.

13. Khasanov I. M. Essence, Mission And Value of Enterpreneurship Activity //The American Journal of Management and Economics Innovations. - 2021. - T. 3. - №. 02. - C. 38-45.

14. Abdurakhmonova M. M., Akramov D. O., Egamberdiev F. A. Conceptual aspects of the development of social work in the new social protection system of Uzbekistan //Chief Editor. 2020. - №. 5. - C. 8.

15. Abdurakhmonova M., Azamjonova $Z$. THE IMPORTANCE OF RAISING THE SOCIAL ACTIVITY OF YOUNG PEOPLE IN THE DEVELOPMENT OF CIVIL SOCIETY //Экономика и социум. 2020. - №. 3. - C. 3-5.

16. Abdurakhmonova M., Akromov D. THE ISSUE OF THE HUMAN FACTOR IN THE DEVELOPMENT OF SOCIETY //Tеория и практика современной науки. - 2020. - №. 3. - C. 3-5.

17. Gaybullaeva M. F. The Role Of Biomass In Saving Natural Resources //The American Journal of Horticulture and Floriculture Research. - 2021. - T. 3. №. 02. - C. 1-6.

18. Oripova G. Uzbek poetry and the world literature in the years of independence //Scientific Journal of Polonia University. - 2019. - T. 32. - №. 1. - C. 116-120.

19. Oripova G. RHYTHM AND MYTHING IN LYRICAL GENRE //Конференции. 2020.

20. Murodilovna O. G. Melody and musicality in Lirycs //ACADEMICIA: An International Multidisciplinary Research Journal. - 2020. - T. 10. - №. 11. - C. 656-664.

21. Butaboev M. T., Karimov U. U. «ЗЕЛЁНАЯ ЭКОНОМИКА». МИРОВОЙ ОПЫТ И ОСОБЕННОСТИ РАЗВИТИЯ В УЗБЕКИСТАНЕ //Theoretical \& Applied Science. - 2020. - №. 2. - C. 704-710.

22. Бутабоев М. Т., Каримов У. У. ПЕРЕХОД К «ЗЕЛЁНОЙ ЭКОНОМИКЕ» И ОСОБЕННОСТИ ЕЁ РАЗВИТИЯ В УЗБЕКИСТАНЕ //Интернаука. - 2020. T. 23. - №. 152 часть 2. - C. 41.

23. A.Abdullaev, Sh.X.Xonkeldiev. Theory and methodology of physical education. Fergana, 2001.

24. Каримова, Г. Й. (2018). РОЛЬ КОНСТИТУЦИИ В ПОСТРОЕНИИ ПРАВОВОГО ГОСУДАРСТВА И ГРАЖДАНСКОГО ОБЩЕСТВА. Теория и практика современной науки, (2), 161-163.

25. T.S.Usmonxodjaev, F.Xodjaev. Physical education in primary grades. Study guide. Tashkent, 1996. 
The American Journal of Applied sciences (ISSN - 2689-0992)

Published: March 27, 2021 | Pages: 22-27

26. Yuldashev I., Toshboltaeva N. I. ANALYSIS OF PERSONALITY TRAITS IN

ATHLETE ACTIVITIES

//Психологическое здоровье населения как важный фактор обеспечения процветания общества. - 2020. - C. 72-74.

27. Yuldashev I. A. PEDAGOGICAL BASES OF FORMATION OF SOCIAL ACTIVITY IN PEDAGOGICAL SCIENCES //Теория и практика современной науки. - 2020. - №. 5. - С. 67-69. 